\title{
Efficacy of Transfer of Heavy Metals in Wheat Grown in Municipal Solid Waste Amended Soil
}

\author{
Zafar I Khan ${ }^{1}$, Ifra S Malik ${ }^{1}$, Kafeel Ahmad ${ }^{1}$, Kinza Wajid ${ }^{1}$, Mudasra Munir ${ }^{1}$, Ilker Ugulu ${ }^{2}$, and Yunus Dogan ${ }^{3 *}$ \\ ${ }^{1}$ Department of Botany, University of Sargodha, Sargodha, Pakistan \\ ${ }^{2}$ Faculty of Education, Usak University, Usak, Turkey \\ ${ }^{3}$ Faculty of Education, Dokuz Eylul University, Izmir, Turkey
}

\begin{abstract}
Municipal solid waste was considered to contain a variety of toxic metals. The heavy metals accumulate in plants due to extensive use of municipal wastes in crops. The current study was conducted to demonstrate the influence of municipal solid waste treatments on the metal content of soil and wheat crop. In this direction, the seeds of wheat variety (Galaxy-13) were sown and four heavy metals $\mathrm{Cd}, \mathrm{Fe}, \mathrm{Zn}$, and Co in grown plants were analysed by using Atomic Absorption Spectrophotometer. The level of metals $(\mathrm{mg} / \mathrm{kg})$ in wheat grains varied from 1.36 to $1.76,9.7$ to $21.2,0.6$ to 0.9 and 0.58 to 0.72 for $\mathrm{Cd}, \mathrm{Fe}, \mathrm{Zn}$ and $\mathrm{Co}$, respectively. Pollution indices were used to determine pollution and accumulation levels. It was observed that bio concentration factor; pollution load index and enrichment factor values of $\mathrm{Cd}$ were high. Finally, it can be said that municipal solid waste must be treated properly before its application on agricultural land to avoid the excessive build-up of heavy metals in the food chain.
\end{abstract}

Keywords: Bioconcentration factor, Heavy metal, Municipal solid waste, Pollution load index, Soil, Triticum aestivum.

\section{INTRODUCTION}

In the developing countries there exist no proper system of treating industrial waste and it is directly poured into the rivers and the fresh water without any treatment as a consequence it not only contaminates the rivers but also harms the life of human and the other living beings (Zeb et al., 2011; Khan et al., 2018a). These waste not only stay in one living who has ingested sewage but it travels to the other organism through a process i.e. food chain (Dogan et al., 2010; Khalid et al., 2011; and Ugulu et al., 2012).

As compared to any other crops', wheat is rapidly growing in more than 240 million hectares. Trade of wheat is higher than all cereals such as maize and rice. Production of wheat in 2009 was 682 million tons. It was the most cultivated cereal after maize ( 817 million tons) and with rice, it is the third one (679 million tons). The normal duration for the cultivation of maize is about 110-130 days. This duration is greatly dependent upon climate type of seed condition of soil and water factor. Among the available nat,ural resources, water is off the critical source which is great being misused (Saleemi, 1993; Ahmad et al., 2018a; Khan et al., 2018b).

Among all the important factors for plant growth, water is of prime importance (Khan et al., 2017; Ahmad et al., 2018b). It is a very precious natural asset and very importance for existence of life (Dogan et al., 2014). It covers an area of about $70 \%$ on earth. Addition of the other substances changes the nature of water and brings physical, chemical and biological changes in the nature of water which consequently leads to disturbance of the ecological balance (Caponera and Alheritiere, 1978; Yasar et al., 2012; Leblebici and Kar, 2018). Heavy metals such as Ni, $\mathrm{Cd}, \mathrm{Pb}, \mathrm{As}, \mathrm{Se}$ and $\mathrm{Hg}$ are causing severe problems throughout the globe (Ahmad and Ashraf, 2011; Ahmad et al., 2012; Unver et al., 2015).The heavy me- tals which come from the industrial water and other sources cause hazardous effects on the life of human, plants, and animals (Jarup, 2003; Azevedo and Lea, 2005; Ugulu et al., 2016).

The current study was aimed to determine the impact of municipal solid waste on morphological parameters and metals uptake by various parts of wheat variety (Galaxy-13).

\section{MATERIALS AND METHOD Study Area}

In order to analyse heavy metal content in the Triticum aestivum variety (Galaxy-13) using municipal solid waste treatment, a pot experiment was conducted. The present research was held at the Department of Botany, University of Sargodha, Sargodha, during the years 2016-2017. The maximum temperature goes up to $50^{\circ} \mathrm{C}$ in summer and minimum up to $12^{\circ} \mathrm{C}$ in winter.

\section{Plant Cultivation}

Healthy seeds of wheat were collected during 2015. The conducted experiment consists of four treatments, with three replicates for the selected crop, in which, twelve pots were filled with soil. The seeds were sown in the pots for different treatment groups. The treatment groups were control group (T-I), no treatment was applied; the remaining three were treated with different percentages of municipal solid waste (T-II, III and IV, respectively). Eight seeds were sowed in each pot. In T-II group, $25 \%$ municipal solid waste and $75 \%$ ground soil were mixed. In T-III group, $50 \%$ municipal solid waste and $50 \%$ ground soil were mixed, however, in group T-IV, 75\% municipal solid waste was used, and the rest was $25 \%$ ground soil. Pot trials were conducted in a natural environment system (November to April) for six months. The experimental pots were irrigated with groundwater. Pots were irrigated with the effluent two times in a week. The data of seed germination was recorded. After germination, for proper 
growth, four plants remained in each pot. Harvesting was done in April 2017, 5 months following the maturation period. Different morphological parameters of were also observed. Growth parameters of different treatment groups compared to control were carried including plant height, the number of leaves per plant and leaf area (Quarrie and Jones 1975) as the following equation:

Leaf area $=$ length $\mathrm{X}$ width $\mathrm{X} 0.75$

\section{Sample Preparation}

After harvesting, the whole plant samples were collected from each pot. The samples after drying in the air were then oven-dried at $72^{\circ} \mathrm{C}$ for few days. After removing from the oven, grains were separated from the spikes and grind in electrical grinder into fine powder, for heavy metal detection $1 \mathrm{~g}$ of each sample was taken. For the digestion of samples, wet digestion method was used.

The dried samples were placed in a small conical flask and digested with conc. $\mathrm{HNO}_{3}$ and $\mathrm{H}_{2} \mathrm{O}_{2}$ (1:2) on a hot plate. When fumes disappear, samples were removed from the heat and $\mathrm{H}_{2} \mathrm{O}_{2}$ was further added to attain transparent solution and again placed on the hot plate. Digestion continued until a colourless solution appears and allow cooling. After cooling, dilute all the samples in a measuring flask up to $50 \mathrm{~mL}$ as final volume. The samples were then filtered through what man filter paper No. 42. The soil samples were collected from the upper $3-5 \mathrm{~cm}$ layer of the soil from each pot. After drying in the air, soil samples were placed in the oven for two days at $65^{\circ} \mathrm{C}$. The samples were digested in the same manner.

\section{Metals Concentration}

All the digested samples were then subjected to Atomic Absorption Spectrophotometer (Perkin-Elmer Corp., 1980) to detect heavy metals $(\mathrm{mg} / \mathrm{kg})$ in them. The metals to be analysed were: cobalt (Co), zinc ( $\mathrm{Zn})$, iron $(\mathrm{Fe})$, and cadmium $(\mathrm{Cd})$. For detection, the standard solution of different metals was also prepared from the stock solution, to obtain a calibration curve. To assess the reliability and assurance of the data, such measures were taken and compared with the interaction standards.

Metal concentration transferred from soil to wheat grains was determined through the bioconcentration factor (BCF) and health risk index (HRI) by following Cui et al., (2004). The pollution load index (PLI) was calculated by the method described by Liu et al., (2005). Daily intake of metals (DIM) was determined using methodology reported by Sajjad et al., (2009) was followed for the calculation of enrichment factor (EF).

\section{Statistical Analysis}

All the results were subjected to analysis of variance (ANOVA) using SPSS software, Version 16.0 (Statistical Package for Social Sciences). Using the software package SPSS (version 16.0), the correlation results were obtained. To assess soil-plant interaction, Pearson's correlation coefficient was calculated. The significant correlation was at $0.5,0.01$ and 0.001 probability levels (Steel and Torrie, 1980).

\section{RESULTS}

\section{Morphological Parameters}

The data recorded (Table 1) for four treatment groups of wheat (Galaxy-13), on root length, leaf length, shoot length, leaf width and leaf area, were significantly different $(p>0.05)$. The maximum values of all these parameters were seen after application of T-4 while the lowest values of these parameters were recorded with T-1. Results showed that sewage sludge significantly increased the concentration of heavy metals in the soil, which exerts toxic effects on cultivated plants. The order for the impact of different municipal treatments on measured morphological parameters was as follow: T-4>T-3>T-2>T-1 (Table 2).

\section{Concentration of Cadmium in Soil and Grain}

The results obtained from ANOVA exhibited nonsignificant impact $(p>0.05)$ of treatments on the concentration of $\mathrm{Cd}$ in soil on which wheat variety

Table (1): Analysis of variance for morphological parameters of wheat variety (Galaxy-13).

\begin{tabular}{ccccccc}
\hline \hline \multirow{2}{*}{$\begin{array}{c}\text { Source of } \\
\text { variety }\end{array}$} & $\begin{array}{c}\text { Degree of } \\
\text { freedom }\end{array}$ & $\begin{array}{c}\text { Root length } \\
(\mathbf{c m})\end{array}$ & $\begin{array}{c}\text { Shoot length } \\
(\mathbf{c m})\end{array}$ & $\begin{array}{c}\text { Leaf length } \\
(\mathbf{c m})\end{array}$ & $\begin{array}{c}\text { Leaf width } \\
(\mathbf{c m})\end{array}$ & $\begin{array}{c}\text { Leaf area } \\
\left(\mathbf{c m}^{2}\right)\end{array}$ \\
\hline $\begin{array}{c}\text { Treatments } \\
\text { Standard } \\
\text { Error }\end{array}$ & 3 & $19.459^{\mathrm{ns}}$ & $57.327^{\mathrm{ns}}$ & $34.010^{\mathrm{ns}}$ & $.030^{\mathrm{ns}}$ & $38.42^{\mathrm{ns}}$ \\
\hline \hline
\end{tabular}

ns, No significant differences were detected among treatments

Table (2): Morphological parameters of wheat variety. All data are in means \pm SE (Galaxy-13).

\begin{tabular}{cccccc}
\hline \hline Treatment & $\begin{array}{c}\text { Root length } \\
(\mathbf{c m})\end{array}$ & $\begin{array}{c}\text { Shoot length } \\
(\mathbf{c m})\end{array}$ & $\begin{array}{c}\text { Leaf length } \\
(\mathbf{c m})\end{array}$ & $\begin{array}{c}\text { Leaf width } \\
(\mathbf{c m})\end{array}$ & $\begin{array}{c}\text { Leaf area } \\
\left(\mathbf{c m}^{2}\right)\end{array}$ \\
\hline T-1 & $11.60 \pm 19$ & $6.83 \pm 1.5$ & $24.27 \pm 3.2$ & $0.67 \pm 0.009$ & $12.06 \pm 1.8$ \\
T-2 & $12.0 \pm 2.8$ & $51.2 \pm 5.5$ & $29.83 \pm 3.4$ & $0.90 \pm 0.080$ & $20.14 \pm 2.8$ \\
T-3 & $6.83 \pm 1.8$ & $57.67 \pm 5.8$ & $29.23 \pm 3.6$ & $0.83 \pm 0.078$ & $18.25 \pm 1.9$ \\
T-4 & $8.17 \pm 1.9$ & $60.67 \pm 6.7$ & $32.3 \pm 4.2$ & $0.77 \pm 0.010$ & $18.78 \pm 2.5$ \\
\hline \hline
\end{tabular}


(Galaxy-2013) was grown (Table 3). The results revealed that the concentration of $\mathrm{Cd}$ was highest in $\mathrm{T}$ IV and was lowest in T-I. The concentration of heavy metal in all treatments ranged from 2.89 to $3.7 \mathrm{mg} / \mathrm{kg}$ respectively (Table 4). Comparison of four different treatments, the mean concentration of $\mathrm{Cd}$ was highest in T-4 while the least concentration was found in T-1.

The results obtained from ANOVA demonstrated the non-significant effect $(p>0.05)$ of treatments on the concentration of $\mathrm{Cd}$ in the grain of wheat variety (Galaxy-2013) (Table 3). The results indicated that the concentration of $\mathrm{Cd}$ was highest in $\mathrm{T}-\mathrm{II}$ and was lowest in T-I. The concentration of heavy metal in all treatments ranged from 1.36 to $1.76 \mathrm{mg} / \mathrm{kg}$ correspondingly (Table 4).

\section{Concentration of Iron in Soil and Grain}

The results obtained from ANOVA exhibited significant influence $(p>0.05)$ of treatments on the concentration of $\mathrm{Fe}$ in soil on which wheat variety (Galaxy-2013) was grown (Table 3). The results revealed that the concentration of Fe was highest in $\mathrm{T}$ IV and was lowest in T-I. The concentration of heavy metal in all treatments ranged from 32.26 to 43.76 $\mathrm{mg} / \mathrm{kg}$ respectively (Table 4). Comparison of four different treatments, the mean concentration of Fe was highest in T-3 while the least concentration was found in T-I.

The results obtained from ANOVA depicted significant impact $(p>0.05)$ of treatments on the concentration of $\mathrm{Fe}$ in the grain of wheat variety (Galaxy-2013) (Table 3). The results showed that the concentration of Fe was highest in T-II and was lowest in T-III. The concentration of heavy metal in all treatments ranged from 12.16 to $21.26 \mathrm{mg} / \mathrm{kg}$ correspondingly (Table 4).

\section{Concentration of Zinc in Soil and Grain}

The results obtained from ANOVA demonstrated non-significant impact $(p>0.05)$ of treatments on the concentration of $\mathrm{Zn}$ in soil on which wheat variety (Galaxy-2013) was grown (Table 3). The results revealed that the concentration of $\mathrm{Zn}$ was highest in $\mathrm{T}$ III and was lowest in T-I. The concentration of heavy metal in all treatments ranged from 2.16 to $3.12 \mathrm{mg} / \mathrm{kg}$ respectively (Table 4). Comparison of four different treatments, the mean concentration of $\mathrm{Zn}$ was highest in T-4 while the least concentration was found in T-I.

The results obtained from ANOVA exhibited nonsignificant impact $(p>0.05)$ of treatments on the concentration of $\mathrm{Co}$ in the grain of wheat variety (Galaxy-2013) (Table 3). The results showed that the concentration of Co was highest in T-III and was lowest in T-I. The concentration of heavy metal in all treatments ranged from 0.66 to $0.72 \mathrm{mg} / \mathrm{kg}$ correspondingly (Table 4).

The results obtained for the concentration of $\mathrm{Zn}$ in the grain of wheat variety (Galaxy-2013), showed nonsignificant influence $(p>0.05)$ of different treatments (Table 3). The concentration of $\mathrm{Zn}$ was recorded in $\mathrm{T}$ III, however, the lowest value was obtained with T-I. The level of heavy metal in all treatments ranged from 0.62 to $0.96 \mathrm{mg} / \mathrm{kg}$, respectively (Table 4). Comparison of four different treatments, the mean concentration of $\mathrm{Zn}$ was highest in $\mathrm{T}-3$, while the least concentration was found in T-I.

Table (3): Analysis of variance for metals in soil and various parts of wheat variety (Galaxy-13).

\begin{tabular}{lllll}
\hline \hline \multirow{2}{*}{ Source } & \multicolumn{4}{c}{ Metal measured } \\
\cline { 2 - 5 } Soil & Cd & Fe & Zn & Co \\
Root & $58.11^{* * *}$ & $213.08^{\mathrm{ns}}$ & $137.70^{\mathrm{ns}}$ & $.108^{\mathrm{ns}}$ \\
Shoot & $331.67^{* * *}$ & $111.68^{\mathrm{ns}}$ & $.009^{\mathrm{ns}}$ & $.012^{\mathrm{ns}}$ \\
Grain & $0.17^{\mathrm{ns}}$ & $89.19^{* * *}$ & $0.013^{* * *}$ & $0.013^{\mathrm{ns}}$ \\
\hline \hline${ }^{* * *}:$ Significant at & 0.001 level, ns: non-significant & $.069^{* * *}$ & $.011^{\mathrm{ns}}$ \\
\hline
\end{tabular}

Table (4): Mean concentration (mg/kg) of $\mathrm{Cd}, \mathrm{Fe}, \mathrm{Zn}$ and Co in soil, root, shoot, and grain (Galaxy-13).

\begin{tabular}{lllll}
\hline \hline Treat & Soil & Root & Shoot & Grain \\
\hline \multicolumn{5}{c}{ Cadmium } \\
T-1 & $2.89 \pm 0.2$ & $2.87 \pm 0.2$ & $2.178 \pm 0.3$ & $1.367 \pm 0.4$ \\
T-2 & $2.90 \pm 0.4$ & $2.98 \pm 0.4$ & $2.367 \pm 0.4$ & $1.767 \pm 0.2$ \\
T-3 & $3.20 \pm 0.4$ & $3.20 \pm 0.3$ & $2.733 \pm 0.3$ & $1.467 \pm 0.3$ \\
T-4 & $3.70 \pm 0.4$ & $2.97 \pm 0.4$ & $2.275 \pm 0.5$ & $1.487 \pm 0.2$ \\
& \multicolumn{5}{c}{ Iron } \\
T-1 & $32.267 \pm 3.2$ & $29.277 \pm 3.1$ & $24.773 \pm 2.5$ & $12.167 \pm 1.6$ \\
T-2 & $35.615 \pm 3.1$ & $31.367 \pm 3.7$ & $27.027 \pm 3.1$ & $21.267 \pm 3.1$ \\
T-3 & $43.765 \pm 4.1$ & $40.77 \pm 4$ & $36.27 \pm 3.5$ & $9.735 \pm 1.4$ \\
T-4 & $43.763 \pm 4.2$ & $36.283 \pm 3.1$ & $27.44 \pm 3.6$ & $18.667 \pm 1.6$ \\
& \multicolumn{5}{c}{ Zinc } \\
T-1 & $2.1633 \pm 0.2$ & $1.767 \pm 0.3$ & $1.44 \pm 0.2$ & $0.625 \pm 0.09$ \\
T-2 & $2.1867 \pm 0.4$ & $1.767 \pm 0.2$ & $1.4667 \pm 0.2$ & $0.867 \pm 0.1$ \\
T-3 & $3.12 \pm 0.2$ & $1.77 \pm 0.3$ & $1.4967 \pm 0.2$ & $0.967 \pm 0.1$ \\
T-4 & $2.275 \pm 0.2$ & $1.867 \pm 0.2$ & $1.5866 \pm 0.2$ & $0.94 \pm 0.07$ \\
& & \multicolumn{5}{c}{ Cobalt } \\
T-1 & $1.0633 \pm 0.05$ & $0.867 \pm 0.03$ & $0.76 \pm 0.05$ & $0.583 \pm 0.06$ \\
T-2 & $1.5083 \pm 0.06$ & $0.967 \pm 0.04$ & $0.867 \pm 0.07$ & $0.667 \pm 0.09$ \\
T-3 & $1.17 \pm 0.07$ & $0.965 \pm 0.05$ & $0.867 \pm 0.09$ & $0.667 \pm 0.07$ \\
T-4 & $1.267 \pm 0.09$ & $1.01 \pm 0.07$ & $0.916 \pm 0.09$ & $0.7283 \pm 0.09$ \\
\hline \hline
\end{tabular}

\section{Concentration of Cobalt in Soil and Grain}

The results obtained from ANOVA depicted nonsignificant effect $(p>0.05)$ of treatments on the concentration of $\mathrm{Co}$ in soil on which wheat variety (Galaxy-2013) was grown (Table 3). The results showed that the concentration of Co was the highest in T-II and was the lowest in T-I. The concentration of heavy metal in all treatments ranged from 1.06 to 1.50 $\mathrm{mg} / \mathrm{kg}$ respectively (Table 4). Comparison of four different treatments, the mean concentration of Co was highest in T-2 while the least concentration was found in T-I.

Bioconcentration Factor, Pollution Load Index and Enrichment Factor of Wheat Variety (Galaxy-13)

Among different metals of four treatments, Cd show- 
ed maximum values for $\mathrm{BCF}$ and it was minimum for $\mathrm{Zn}$. The sequence of $\mathrm{BCF}$ at $\mathrm{T}-\mathrm{I}$ and T-II was: $\mathrm{Cd}>\mathrm{Fe}>\mathrm{Zn}>\mathrm{Co}$, at $\mathrm{T}$-III was: $\mathrm{Cd}>\mathrm{Fe}>\mathrm{Co}>\mathrm{Zn}$, while at T-IV it was found in following the decreasing order: $\mathrm{Fe}>\mathrm{Zn}>\mathrm{Cd}>\mathrm{Co}$ (Table 5).

The sequence of pollution load index at all treatments was: $\mathrm{Cd}>\mathrm{Fe}>\mathrm{Zn}>\mathrm{Co} \quad$ (Table 5). The pollution level or contamination factor of $\mathrm{Cd}$ was higher in all the four treatments while $\mathrm{Zn}$ and Co were the lowest in all of the four treatments. Heavy metals are hazardous to health if PLI value is $(>1)$. In the present investigation, $\mathrm{Cd}$ was (>1). And $\mathrm{Fe}, \mathrm{Co}$, and $\mathrm{Zn}$ were lower than 1.

The sequence of EF at T-I, T-III and T-IV were: $\mathrm{Zn}>\mathrm{Co}>\mathrm{Cd}>\mathrm{Fe}$, while at T-II was: $\mathrm{Zn}>\mathrm{Cd}>\mathrm{Co}>\mathrm{Fe}$. When EF was $(>1)$ it indicates higher availability and distribution of metals (Table 5).

Table (5): Bioconcentration factor, pollution load index and enrichment factor for wheat variety (Galaxy13).

\begin{tabular}{lllll}
\hline & \multicolumn{4}{c}{ Bioconcentration factor } \\
\cline { 2 - 5 } Treatment & \multicolumn{4}{c}{ Heavy metal measured } \\
\cline { 2 - 5 } & Cd & Fe & Zn & Co \\
\hline T-1 & 0.9941 & 0.907 & 0.817 & 0.815 \\
T-2 & 1.0275 & 0.881 & 0.808 & 0.641 \\
T-3 & 1.000 & 0.932 & 0.567 & 0.825 \\
T-4 & 0.802 & 0.829 & 0.821 & 0.797 \\
& & Pollution load index & \\
T-1 & 27.009 & 0.567 & 0.048 & 0.203 \\
T-2 & 27.103 & 0.626 & 0.049 & 0.288 \\
T-3 & 29.907 & 0.769 & 0.070 & 0.224 \\
T-4 & 34.580 & 0.769 & 0.051 & 0.242 \\
& & Enrichment factor & \\
T-1 & 0.0844 & 0.0504 & 0.1284 & 0.100 \\
T-2 & 0.1479 & 0.0798 & 0.1762 & 0.080 \\
T-3 & 0.1001 & 0.0297 & 0.1377 & 0.104 \\
T-4 & 0.0703 & 0.0570 & 0.1836 & 0.105 \\
\hline \hline
\end{tabular}

Transfer Factor (Root-Shoot and Shoot-Grain) of Wheat Variety (Galaxy-13)

Among different metals, Co showed higher values for TF and it was lower for Fe. The order of TF at T-I, $\mathrm{T}$-II and T-III was: $\mathrm{Co}>\mathrm{Fe}>\mathrm{Zn}>\mathrm{Cd}$, while at $\mathrm{T}$-IV was: $\mathrm{Co}>\mathrm{Zn}>\mathrm{Cd}>\mathrm{Fe}$ (Table 6).

The transfer factor from shoot to grain for all metals and metalloids showing the following results, the sequence of TF at T-I was: $\mathrm{Co}>\mathrm{Cd}>\mathrm{Fe}>\mathrm{Zn}$, at T-II was: $\mathrm{Fe}>\mathrm{Co}>\mathrm{Cd}>\mathrm{Zn}$, at $\mathrm{T}$-III was: $\mathrm{Co}>\mathrm{Zn}>\mathrm{Cd}>\mathrm{Fe}$, while at T-IV was: $\mathrm{Co}>\mathrm{Fe}>\mathrm{Cd}>\mathrm{Zn}$ (Table 6).

Daily Intake of Metal and Health Risk Index in Wheat Variety (Galaxy-13)

Among four treatments, DIM for $\mathrm{Fe}$ and $\mathrm{Cd}$ was higher in all the treatments while lower for $\mathrm{Zn}$ and Co. The sequence of DIM at all treatments was: $\mathrm{Fe}>\mathrm{Cd}>\mathrm{Zn}>\mathrm{Co}$ (Table 7).

This result demonstrated that HRI of Cd was $(>1)$ in all the four treatments above the possible limit. The sequence of $\mathrm{HRI}$ at T-I was: $\mathrm{Cd}>\mathrm{Fe}>\mathrm{Zn}>\mathrm{Co}$, while at T-II, T-III and T-IV it was: $\mathrm{Cd}>\mathrm{Fe}>\mathrm{Co}>\mathrm{Zn}$ (Table 7).

Table (6): Transfer factor for all heavy metals of wheat variety (Galaxy-13).

\begin{tabular}{lcccc}
\hline \hline \multirow{5}{*}{ Treatment } & \multicolumn{5}{c}{ Heavy metal measured } \\
\cline { 2 - 5 } T-1 & Cd & Fe & Zn & Co \\
\hline Root-Shoot & \\
T-2 & 0.7581 & 0.8461 & 0.8149 & 0.8765 \\
T-3 & 0.7941 & 0.8616 & 0.8300 & 0.8965 \\
T-4 & 0.8540 & 0.8896 & 0.8455 & 0.8984 \\
& 0.7667 & 0.7562 & 0.8498 & 0.9076 \\
& & Shoot-Grain & & \\
T-1 & 0.6274 & 0.4911 & 0.4340 & 0.7671 \\
T-2 & 0.7464 & 0.7868 & 0.5911 & 0.7693 \\
T-3 & 0.5366 & 0.2684 & 0.6460 & 0.7693 \\
T-4 & 0.6534 & 0.6802 & 0.5924 & 0.7944 \\
\hline \hline
\end{tabular}

Table (7): Daily intake of metal and health risk index via intake of wheat variety (Galaxy-13).

\begin{tabular}{|c|c|c|c|c|}
\hline \multirow{2}{*}{ Treatment } & \multicolumn{4}{|c|}{ Heavy metal measured } \\
\hline & Cd & $\mathbf{F e}$ & Zn & Co \\
\hline \multicolumn{5}{|c|}{ Daily intake of metals } \\
\hline T-1 & 0.008 & 0.0699 & 0.0049 & 0.0038 \\
\hline T-2 & 0.0101 & 0.1222 & 0.0055 & 0.0038 \\
\hline T-3 & 0.008 & 0.0559 & 0.0054 & 0.0041 \\
\hline T-4 & 0.009 & 0.1073 & 0.0054 & 0.0041 \\
\hline \multicolumn{5}{|c|}{ Health risk index } \\
\hline T-1 & 7.859 & 0.699 & 0.009 & 0.077 \\
\hline T-2 & 10.159 & 1.222 & 0.013 & 0.089 \\
\hline T-3 & 8.434 & 0.559 & 0.015 & 0.089 \\
\hline T-4 & 8.549 & 1.073 & 0.014 & 0.097 \\
\hline
\end{tabular}

\section{Correlation of Wheat Variety (Galaxy-13)}

The result showed that from root to shoot, $\mathrm{Fe}$ and $\mathrm{Co}$ exhibited positive and non-significant correlation, and $\mathrm{Cd}$ and $\mathrm{Zn}$ showed negative and non-significant correlation. In present investigation from root to shoot the Co exhibited positive and highly significant correlation while $\mathrm{Cd}, \mathrm{Fe}$, and $\mathrm{Zn}$ showed positive and non-significant correlation. The results of correlation among grains of wheat give highly significant and 
positive correlation of and Co while positive and nonsignificant effect showed by $\mathrm{Cd}, \mathrm{Fe}$, and $\mathrm{Zn}$ (Table 8).

Table (8): Metal correlation between different levels of wheat variety (Galaxy-13).

\begin{tabular}{cccc}
\hline \hline $\begin{array}{c}\text { Metal } \\
\text { measured }\end{array}$ & Soil-Root & Root-Shoot & Shoot-Grain \\
\hline Cd & -0.274 & 0.071 & 0.098 \\
$\mathbf{F e}$ & 0.044 & 0.345 & 0.107 \\
$\mathbf{Z n}$ & -0.300 & 0.941 & 0.683 \\
$\mathbf{C o}$ & 0.571 & $1.000^{* *}$ & $0.990^{* * *}$ \\
\hline
\end{tabular}

** Significant at 0.01 level.

\section{DISCUSSION}

The influence of municipal treatment on wheat as a cultivated plant in the present study was evaluated through growth measurement including leaf length, root, shoot lengths and leaf area, which reflect the significant differences in all treatment compared to control. These results were in agreement with data obtained by Metwali et al., (2013).

Wastewater is one of the significant factors behind low productivity of crops as reported by Konwar and Jha (2010). Due to high toxicity, Cd has a lousy repute and unapproachable to the growth of plants (Iqbal and Mehmood, 1991). The mean level of $\mathrm{Cd}$ in soil ranged from 2.8 to $3.7 \mathrm{mg} / \mathrm{kg}$. The value of $\mathrm{Cd}$ was similar to the value that is $2.8 \mathrm{mg} / \mathrm{kg}$ given by Hassan et al., (2013). The amount of Cd was lower, that was 0.20 $\mathrm{mg} / \mathrm{kg}$ given by Rattan et al., (2005) as compared to the present study. Geochemically $\mathrm{Cd}$ was the relatively movable element in soil, and it was quickly taken up by plants. Narwal et al., (1993) stated that the concentration of metals such as $\mathrm{Cd}$ and $\mathrm{Zn}$ in soil and plant increased when municipal solid waste was applied to agricultural land.

Industrial wastewater that has high metal value is dangerous to all living forms. In the present study, the soil level of Fe fluctuated from 32.26 to $43.76 \mathrm{mg} / \mathrm{kg}$. The Fe concentration was lower as compared to the value of $270 \mathrm{mg} / \mathrm{kg}$ given by Hassan et al., (2013) and the value that was $2.05 \mathrm{mg} / \mathrm{kg}$ given by Mojiri and Aziz (2011). Kansal et al., (1996) gathered plant samples of various crops from sewage irrigated soils and found that these plants contained a more significant amount of $\mathrm{Fe}$ than plants from tube wellirrigated soils. The value of Fe was lower, that was $20.1 \mathrm{mg} / \mathrm{kg}$ given by Rattan et al., (2005) as compared to the present study. Iron concentration $6205 \mathrm{mg} / \mathrm{kg}$ given by Ekmekyapar et al., (2012) was higher than the current value.

In the soil level of $\mathrm{Zn}$ varied from 2.16 to $3.12 \mathrm{mg} / \mathrm{kg}$ in the present study. The value of $\mathrm{Zn}$ was higher that was $7.31 \mathrm{mg} / \mathrm{kg}$ given by Rattan et al., (2005) as compared to the present study. In the current study, the lower value of zinc was observed as compared to value $129.08 \mathrm{mg} / \mathrm{kg}$ given by $\mathrm{Yu}$ et al., (2016). Zinc value of the current study was lower by the value of 12.235 $\mathrm{mg} / \mathrm{kg}$ according to Asdeo (2014). The lower concentration of $\mathrm{Zn}$ in the current study was observed as compared to the values given by Hassan et al., (2013) that was $135 \mathrm{mg} / \mathrm{kg}$.

Level of Co fluctuated from 1.06 to $1.26 \mathrm{mg} / \mathrm{kg}$. The value of Co $1.73 \mathrm{mg} / \mathrm{kg}$ was given by Ahmad et al., (2014) was close to current value. The 17.63 value of Co was given by Bibi et al., (2014) that was higher to the current study. Cobalt concentration was lower in the present study to value $18.9 \mathrm{mg} / \mathrm{kg}$ given by Page et al., (2006).

The level of Cd varied from 1.36 to $1.76 \mathrm{mg} / \mathrm{kg}$ in grains of wheat. In the current study, the value of $\mathrm{Cd}$ was higher as compared to value $0.062 \mathrm{mg} / \mathrm{kg}$ given by $\mathrm{Yu}$ et al., (2016). The concentration of $\mathrm{Cd}$ was higher in current to value $0.10 \mathrm{mg} / \mathrm{kg}$ estimated by Stefanović et al., (2008). Cadmium affects negatively if accumulates in the body of the human and affects several organs: lung, liver, bones, kidney, central nervous system, placenta and brain (Castro-Gonzalez and Mendez-Armenta, 2008). The other damages that have been detected include development toxicity, hematological effects of hepatic and reproductive disorders (Apostoli and Catalani, 2011).

The level of $\mathrm{Cd}$ in current findings exceeded the tolerable range $(0.2 \mathrm{mg} / \mathrm{kg})$ (Arduini et al., 2014). Kansal et al. (1996) also reported that sewage irrigated vegetables contain the high level of $\mathrm{Cd}$ and $\mathrm{Fe}$ as compared to canal and tube well-irrigated water. The concentration of $\mathrm{Fe}$ in grains of wheat in the present study ranged from 9.7 to $21.26 \mathrm{mg} / \mathrm{kg}$. Iron concentration $151 \mathrm{mg} / \mathrm{kg}$ given by Ekmekyapar et al., (2012) was higher to present value. The value of $\mathrm{Fe}$ in current research was higher than the value $2.28 \mathrm{mg} / \mathrm{kg}$ of $\mathrm{Fe}$ reported by Nadim et al., (2013) in different varieties of wheat grains. Iron was an essential element because it was existed in all living organisms. Iron was an essential element of haemoglobin, functions in the transport of oxygen. It was usually taken as a border between micro and macro-elements of the living organisms.

In grains of wheat, the concentration of $\mathrm{Zn}$ in the present study ranged from 0.62 to $0.96 \mathrm{mg} / \mathrm{kg}$. The concentration of $\mathrm{Zn}$ was lower in the current study to value $24.13 \mathrm{mg} / \mathrm{kg}$ given by Stefanović et al., (2008). Increasing anthropogenic influences on the environment, especially pollution loadings, have caused negative changes in natural ecosystems: decreased biodiversity, simplified structure, and lowered productivity (Durkan et al., 2011). For example, Zn occurs naturally in air, water, and soil, but as a result of human activities, its concentrations are raising unnaturally (Baslar et al., 2009a, b).

In the current research, the Co concentration in grains of wheat variety ranged from 0.58 to $0.728 \mathrm{mg} / \mathrm{kg}$. The value of cobalt was higher to present value 5.340 $\mathrm{mg} / \mathrm{kg}$ given by Samera et al., (2014). The cobalt concentration was lower in the current study to value $81.1 \mathrm{mg} / \mathrm{kg}$ demonstrated by Page et al., (2006). The value was higher was higher to the value reported by Shad et al., (2014) that was $0.15 \mathrm{mg} / \mathrm{kg}$ in grains of wheat. Mostly the high Co concentration is present in leafy plants and lower concentration in grasses and 
cereals.

In the present study, $\mathrm{BCF}$ value $\mathrm{Zn}$ and $\mathrm{Cd}$ were higher than in a work in which concentration of $\mathrm{Cd}$ and $\mathrm{Zn}$ were 0.08 and 0.25 correspondingly (Puschenreiter et al., 2005). The bioconcentration factor values of $\mathrm{Cd}$ and $\mathrm{Zn}$ were higher in current research as compared to values of BCF demonstrated by Asdeo (2014). The lower values of $\mathrm{BCF}$ in current findings were detected as compared to values given by Khan et al., (2016).

The pollution load index value of $\mathrm{Zn}$ and $\mathrm{Cd}$ was lower from the values 2.1 and 84.0 respectively. The pollution load index value $(>1)$ demonstrated that soil is contaminated while PLI $<1$ indicated that soil is unpolluted (Harikumar et al., 2009). In current findings PLI for Fe, Zn and Co were (>1). High PLI was noticed for Cd in T-IV due to the high proportion of municipal solid waste.

The level of metal toxicity in humans depends on their daily intake. The daily intake of metal contaminated food crops direct effect on consumer's health. If $\mathrm{DIM}>1$, the population of the country will be at greater risk (Sajjad et al., 2009). In the current findings, values of DIM for all metals were below 1 . The average daily wheat grain intakes for adults and 0-6year-old children were estimated to be 0.315 and $0.0437 \mathrm{mg} / \mathrm{kg} /$ day respectively. While the adult and 0 6-year-old child, average body weights were estimated to be 61.6 and $18.6 \mathrm{~kg}$, respectively demonstrated by Wang et al., (2009).

In the current findings, level of Cd wad very high which exerts the hazardous effect on human health. Our results were similar to the findings of Singh et al., (2010). Our results were similar to Cui et al., (2004) who stated that the accumulation of $\mathrm{Fe}$ has the lower health risk. Health risk index of Co was lower and higher value of $\mathrm{Zn}$ was observed in the current study as compared to the values of health risk index given by Bibi et al., (2014). The values of HRI of Cd in current research work were lower to value given by Khan and Khan (2010).

The enrichment factor value given by Likuku et al., (2013) was higher while Zn 1.25 was higher as compared to the present value. The enrichment factor of $\mathrm{Zn}$ and $\mathrm{Cd}$ was higher however other heavy metals have lower as compared to values given by Olubunmi (2010). The heavy metals enrichment factor depends upon metals bioavailability in the soil. The metals bioavailability depends upon their chemical forms, their concentration in the soil, plant species growth rate and difference in uptake capability of plants (Tinker, 1981). In the present research work, the positive and nonsignificant findings were seen for Fe among the soil and the crop as opposed to the work reported by Khan et al., (2015). Positive and non-significant correlations were also observed by Khan et al., (2013) for metal Zn.

\section{CONCLUSION}

In the current investigation, increased concentration of $\mathrm{Cd}$ was observed in soil and grains treated with diverse doses of domestic wastewater. Cadmium could be considered potentially dangerous as it exceeded WHO limits and its HRI value was $>1$. This could be due to the application of untreated wastewater. So, therefore, we must have to pass this solid waste through proper treatment to decrease its harmful effect.

\section{CONFLICTS OF INTEREST}

The authors declare that there are no conflicts of interest regarding the publication of this paper.

\section{REFERENCES}

AHMAD, I., M.J. AKHTAR., Z.A. ZAHIR., AND A. JAMIL. 2012. Effect of Cd on seed germination and seedling growth of four wheat cultivars. Pakistan Journal of Botany 44 (5): 1569-1574.

AHMAD, K., A. ASHFAQ., Z.I. KHAN., H. BASHIR., M. SOHAIL., N. MEHMOOD., AND Y. DOGAN. 2018a. Metal accumulation in Raphanus sativus and Brassica rapa: An assessment of potential health risk for inhabitants in Punjab, Pakistan. Environmental Science and Pollution Research 25 (8): 16676-16,685.

AHMAD, K., Z.I. KHAN., A. ASHFAQ., M. ASHRAF., AND S. YASMIN. 2014. Assessment of heavy metal and metalloid levels in spinach (Spinacia oleracea L.) grown in wastewater irrigated agricultural soil of Sargodha, Pakistan. Pakistan Journal of Botany 46 (5): 1805-1810.

AHMAD, M.S.A., AND M. ASHRAF. 2011. Essential roles and hazardous effects of nickel in plants. Reviews of Environmental Contamination and Toxicology 214 (1): 125-167.

APOSTOLI, P., AND S. CATALANI. 2011. Metal ions affecting reproduction and development. Metal Ions in Life Science 8: 263-303.

ARDUINI, I., A. MASONI., M. MARIOTTI., S. PAMPANA., AND L. ERCOLI. 2014. Cadmium uptake and translocation in durum wheat varieties differing in grain-Cd accumulation. Plant, Soil and Environment 60 (1): 43-49.

ASDEO, A. 2014. Toxic metal contamination of staple crops (wheat and millet) in periurban area of Western Rajasthan. International Refereed Journal of Engineering and Science 3 (4): 8-18.

AZEVEDO, R.A., AND P.J. LEA. 2005. Toxic metals in plants. Brazilian Journal of Plant Physiology 17 (1): 1 .

BASLAR, S., Y. DOGAN., N. DURKAN., AND H. BAG. 2009a. Biomonitoring of zinc and manganese in bark of Turkish red pine of Western Anatolia. Journal of Environmental Biology 30: 831-834.

BASLAR, S., I. KULA, Y. DOGAN, D. YILDIZ, AND G. AY. 2009b. A study of trace element contents in plants growing at Honaz Dagi-Denizli, Turkey. Ekoloji 18(72): 1-7.

BIBI, Z., Z.I. KHAN., K. AHMAD., M. ASHRAF., A. HUSSAIN., AND N.A. AKRAM. 2014. Vegetables as a potential source of metals and metalloids for human nutrition: A case study of Momordica charantia grown in soil irrigated with domestic 
sewage water in Sargodha, Pakistan. Pakistan Journal of Zoology 46 (3): 633-641.

CAPONERA, D.A., AND D. ALHÉRITIÈRE. 1978. Principles for international ground-water law (II). Natural Resources Forum 2 (4): 359-371.

CASTRO-GONZALEZ., M.I., AND M. MENDEZARMENTA. 2008. Heavy metals: Implications associated to fish consumption. Environmental Toxicology and Pharmacology 26: 263-271.

CUI, Y.G., Y.G. ZHU., R.H. ZHAI., D.Y. CHEN., Y.Z. HUANG., Y. QUI., AND J.Z. LIANG. 2004. Transfer of metals from near a smelter in Nanning, China. Environment International 30: 785-791.

DOGAN, Y., I. UGULU., AND S. BASLAR. 2010. Turkish red pine as a biomonitor: A comperative study of the accumulation of trace elements in needles and barks. Ekoloji 19 (75): 88-96.

DOGAN, Y., S. BASLAR., AND I. UGULU. 2014. A study on detecting heavy metal accumulation through biomonitoring: Content of trace elements in plants at Mount Kazdagi in Turkey. Applied Ecology and Environmental Research 12 (3): 627 636.

DURKAN, N., I. UGULU., M.C. UNVER., Y. DOGAN., AND S. BASLAR. 2011. Concentrations of trace elements aluminum, boron, cobalt and tin in various wild edible mushroom species from Buyuk Menderes River Basin of Turkey by ICPOES. Trace Elements and Electrolytes 28 (4): 242248.

EKMEKYAPAR, F., T. SABUDAK., AND G. SEREN. 2012. Assessment of heavy metal contamination in soil and wheat (Triticum aestivum L.) plant around the Corlu-Cerkezkoy highway in Thrace Region. Global Nest Journal 14 (4): 496504.

HARIKUMAR, P.S., U.P. NASIR, AND M.P. MUJEEBU RAHMAN. 2009. Distribution of heavy metals in the core sediments of a tropical wetland system. International Journal of Environmental Science and Technology 6(2): 225-232.

HASSAN, N.U., Q. MAHMOOD., A. ISEEM., M. IRSHAD., FARIDULLAH., AND A. PERVEZ. 2013. Assessment of heavy metals in wheat plants irrigated with contaminated wastewater. Polish Journal of Environmental Studies 22 (1): 115-123.

IQBAL, M.Z., AND T. MEHMOOD. 1991. Influence of cadmium toxicity on generation and growth of some common trees. Pakistan Journal of Scientific and Industrial Research 34: 140-142.

JARUP, L. 2003. Hazards of heavy metal contamination. British Medical Bulletin 68: $167-$ 182.

KANSAL, B.D., R. KUMAR., AND R. SOKKA. 1996. The influence of municipal wastes and soil properties on the accumulation of heavy metals in plants. In: Lekkas T.D. (Ed.). Heavy metals in the environment. CEC Consultants Ltd., Edinburg, pp. 413-416.

KHALID, A., A.H. MALIK., A. WASEEM., S. ZAHRA., AND G. MURTAZA. 2011. Qualitative and quantitative analysis of drinking water samples of different localities in District Abbottabad, Pakistan. International Journal of Physical Sciences 6 (33): 7480-7489.

KHAN, A., S. KHAN., M.A. KHAN., Z. QAMAR., AND M. WAQAS. 2015. The uptake and bioaccumulation of heavy metals by food plants, their effects on plants nutrients, and associated health risk: A review. Environmental Science and Pollution Research 22: 72-99.

KHAN, M.R., AND M.M. KHAN. 2010. Effect of varying concentration of nickel and cobalt on the plant growth and yield of chickpea. Australian Journal of Basic and Applied Sciences 4: 10361046.

KHAN, Z.I., K. AHMAD., H. SAFDAR., I. UGULU., K. WAJID., H. BASHIR., AND Y. DOGAN. 2018b. Manganese bioaccumulation and translocation of in forages grown in soil irrigated with city effluent: An evaluation on health risk. Research Journal of Pharmaceutical, Biological and Chemical Sciences 9 (5): 759-770.

KHAN, Z.I., K. AHMAD., M. ASHRAF., N.A. AKRAM., Y. RIZWAN., M. SHAHEEN., AND F. ARSHAD. 2013. Assessment of potential toxicological risk for public health of heavy metals in wheat crop irrigated with wastewater: A case study in Sargodha, Pakistan. Asian Journal of Chemistry 25 (17): 9704-9706.

KHAN, Z.I., K. AHMAD., M. ASHRAF., S. YASMEEN., A. ASHFAQ., AND M. SHER. 2016. Metal accumulation in a potential winter vegetable mustard (Brassica campestris L.) irrigated with different types of waters in Punjab, Pakistan. Pakistan Journal of Botany 48 (2): 535-541.

KHAN, Z.I., K. AHMAD., S. IQBAL., A. ASHFAQ., H. BASHIR., N. MEHMOOD., AND Y. DOGAN. 2018a. Evaluation of heavy metals uptake by wheat growing in sewage water irrigated soil. Human and Ecological Risk Assessment 24 (5): 1409-1420.

KHAN, Z.I., S. IQBAL., F. BATOOL., K. AHMAD., M.S. ELSHIKH., A. AL SAHLI. 2017. Evaluation of heavy metals uptake by wheat growing in sewage irrigated soil: Relationship with heavy metal in soil and wheat grains. Fresenius Environmental Bulletin 26 (12): 7838-7848.

KONWAR, D., AND D.K. JHA. 2010. Response of rice (Oryza sativa L.) to contamination of soil with refinery effluents under natural conditions. Assam University Journal of Science and Technology 5 (1): $14-22$.

LEBLEBICI, Z., AND M. KAR. 2018. Heavy metals accumulation in vegetables irrigated with different water sources and their human daily intake in Nevsehir. Journal of Agricultural Science and Technology 20 (2): 401-415.

LIKUKU, A.S., K.B. MMOLAWA., AND G.K. GABOULTLOELOE. 2013. Assessment of heavy metal enrichment and degree of contamination around the copper-nickel mine in the Selebi Phikwe region, Eastern Botswana. Environment and Ecology Research 1 (2): 32-40.

LIU, W.H., J.Z. ZHAO., Z.Y. OUYANG., L. 
SODERLUND., AND G.H. LIU. 2005. Impacts of sewage irrigation on heavy metals distribution and contamination in Beijing, China. Environment International 31: 805-812.

METWALI, M.R., S.M. GOWAYED., O.A. ALMAGHRABI., AND Y.Y. MOSLEH. 2013. Evaluation of toxic effect of copper and cadmium on growth, physiological traits and protein profile of wheat (Triticum aestivium L.), maize (Zea mays L.) and sorghum (Sorghum bicolor L.). World Applied Sciences Journal 21 (3): 301-304.

MOJIRI, A., AND H.A. AZIZ. 2011. Effects of municipal wastewater on accumulation of heavy metals in soil and wheat (Triticum aestivum L.) with two irrigation methods. Romanian Agricultural Research 28: 217-222.

NADIM, M.A., I.U. AWAN., M.S. BALOCH., N. KHAN., AND K. NAVEED. 2013. Micronutrient use efficiency in wheat as affected by different application methods. Pakistan Journal of Botany 45 (3): 887-892.

NARWAL, R.P., M. SINGH., J.P. SINGH., AND D.J. DAHIYA. 1993. Cadmium-zinc interaction in maize grown on sewer water irrigated soil. Arid Land Research and Management 7 (2): 125-131.

OLUBUNMI, F.E. 2010. Evaluation of the status of heavy metal pollution of sediment of Agbabu Bitumen deposit area, Nigeria. European Journal of Scientific Research 41 (3): 373-382.

PAGE, V., R.C.L. BAYON., AND U. FELLER. 2006. Partitioning of zinc, cadmium, manganese and cobalt in wheat (Triticum aestivum) and lupine (Lupinus albus) and further release into the soil. Environmental and Experimental Botany 58: 269278.

PUSCHENREITER, M., O. HORAK, W. FRIESL, AND W. HARTL. 2005. Low-cost agricultural measures to reduce heavy metal transfer into the food chain-a review. Plant, Soil and Environment 51(1): 1-11.

QUARRIE, S.A., AND H.G. JONES. 1977. Effects of abscise acid and water stress on development and morphology of wheat. Journal of Experimental Botany 28 (102): 192-203.

RATTAN, R.K., S.P. DATTA., P.K. CHHONKAR., K. SURIBABU., AND A.K. SINGH. 2005. Longterm impact of irrigation with sewage effluents on heavy metal content in soils, crops and groundwater - A case study. Agriculture, Ecosystems \& Environment 109: 310-322.

SAJJAD, K., R. FAROOQ., S. SHAHBAZ., M.A. KHAN., AND M. SADIQUE. 2009. Health risk assessment of heavy metals for population via consumption of vegetables. World Applied Sciences Journal 6: 1602-1606.

SALEEMI, M.A. 1993. Environmental assessment and management of irrigation and drainage scheme for sustainable agriculture growth. EPA, Lahore.

SAMERA, B., P. DEVI., N. GOGOI., AND Y.M. DEVI. 2014. Effects of cobalt induced stress on
Triticum aestivum L. crop. Asian Journal of Agriculture and Biology 2 (2): 137-147.

SHAD, H.A., Z.I. KHAN., K. AHMAD., Y. RIZWAN., AND H.M. TAHIR. 2014. Human health hazards caused by heavy metals accumulation in wheat variety "Sehar-2006" irrigated with domestic sewage water. Biologia (Pakistan) 60 (1): 99-102.

SINGH, A., R.K. SHARMA., M. AGRAWAL., AND F.M. MARSHALL. 2010. Health risk assessment of heavy metals via dietary intake of food stuffs from thewaste water irrigated site of a dry tropical area of India. Food and Chemical Toxicology 48: 611619.

STEEL, R.G.D., AND J.H. TORRIE. 1980. Principles and procedures of statistics, a biometrical approach, 2. McGraw-Hill, New York.

STEFANOVIĆ, V.Ž., N.K. FILIPOVIĆ., AND B.M. JOVANOVIĆ. 2008. Undesirable metals content in wheat of different wheat varieties. Acta Periodica Technologica 39: 69-76.

TINKER, P.B. 1981. Levels, distribution and chemical forms of trace elements in food plants. Philosophical Transactions of the Royal Society of London. Series B, Biological Sciences 294: 41-55.

UGULU, I., M.C. UNVER., AND Y. DOGAN. 2016. Determination and comparison of heavy metal accumulation level of Ficus carica bark and leaf samples in Artvin, Turkey. Oxidation Communications 39 (1-2): 765-775.

UGULU, I., Y. DOGAN., S. BASLAR., AND O. VAROL. 2012. Bio monitoring of trace element accumulation in plants growing at Murat Mountain. International Journal of Environmental Science and Technology 9: 527-534.

UNVER, M.C., I. UGULU, N. DURKAN, S. BASLAR, AND Y. DOGAN. 2015. Heavy metal contents of Malva sylvestris sold as edible greens in the local markets of Izmir. Ekoloji 24 (96): 13-25.

WANG, C., S.H. ZHANG., P.F. WANG., J. HOU., W.J. ZHANG., W. LI., AND Z.P. LIN. 2009. The effect of excess zinc on mineral nutrition and antioxidative response in rapeseed seedling. Chemosphere 75: 1468-1476.

YASAR, U., I.I. OZYIGIT., I.E. YALCIN., I. DOGAN., AND G. DEMIR. 2012. Determination of Some Heavy Metals and Mineral Nutrients of Bay Tree (Laurus nobilis L.) in Bartin City, Turkey. Pakistan Journal of Botany 44: 81-89.

YU, X. Z. WANG., A. LYNN., J. CAI, Y. HUANGFU., Y. GENG., J. TANG., AND X. ZENG. 2016. Heavy metals in wheat grown in sewage irrigation: A distribution and prediction model. Polish Journal of Environmental Studies 25 (1): 413-418.

ZEB, B.S., A.H. MALIK., A. WASEEM., AND Q. MAHMOOD. 2011. Water quality assessment of Siran River, Pakistan. International Journal of Physical Sciences 6 (34): 7789-7798. 